\title{
Penerapan Model Pembelajaran Discovery Learning Untuk Meningkatkan Prestasi Belajar Siswa
}

\author{
Sri Muwarni a, $1^{\star}$ \\ a SMP Negeri 3 Sukoharjo, Sukoharjo, Indonesia \\ 1 srimuwarni_sunar@yahoo.com* \\ * Corresponding Author
}

Diterima 28 Desember 2020; Disetujui 17 Maret 2021; Diterbitkan 18 Maret 2021

\begin{abstract}
The objective of this classroom action research is to improve students' learning achievement of Mathematics through Discovery Learning Model in the class of VII during the 2nd semester at SMP Negeri 3 Sukoharjo in the academic year 2019/2020. This research is conducted from January to Juni 2020 at SMP Negeri 3 Sukoharjo. The subjects are 32 students of class VII G. This research is desaigned in two cycles. The data collection techniques are documentation, observation, and written tests. The data collection tools are observation sheets, test items, and score list documents. Analysis data use comparative descriptive analysis followed by reflection on each cycle consists of four steps, namely: (1) Planning, (2) Action Implementation, (3) observation, and (4) reflection. The results of this research indicate the increasing in students' mathematics learning achievement. It can be seen from the average of learning achievement score of mathematics subjects, where the average score before action is 64,5 , the average score of the first cycle is 72,3 and average score of the second cycle is 80,2 . In addition, the percentage of students' learning mastery increase, before the action of $40,6 \%$, in the first cycle of $68,8 \%$ and in the second cycle of $90,6 \%$. So, it can be concluded that the Discovery Learning can improve the learning process and the mathematics learning achievement in the class VII G during the 2nd semester at SMP Negeri 3 Sukoharjo in the academic year 2019/2020.
\end{abstract}

KEYWORDS

mathematics learning achievement discovery learning

This is an openaccess article under the CC-BY-SA license

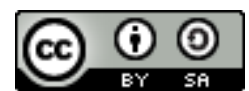

\section{Pendahuluan}

Pelajaran matematika diberikan kepada jenjang pendidikan SMP pada kurikulum 2013. Banyak guru yang menyadari bahwa matematika dianggap sebagai pelajaran yang membosankan oleh sebagian besar siswa, sehingga banyak siswa yang mengeluh tentang kesulitan belajar dalam mengikuti pembelajaran matematika. Dari hasil penelitian terdahulu, menyimpulkan bahwa dari 20 responden, ada 16 responden yang mengatakan bahwa matematika adalah mata pelajaran yang cukup sulit dan sulit (Siregar 2017). Kesulitan ini sering kita jumpai pada saat proses pembelajaran berlangsung. Selain itu juga ketika pembelajaran berlangsung masih terlihat siswa yang kurang merespon dengan baik apa yang diminta guru, hanya beberapa yang mau mengerjakan soal latihan yang diberikan guru, serta masih ada yang pasif dan kurang antusias dalam belajar. Minat belajar siswa dirasa juga masih kurang karena pembelajaran matematika yang menurut siswa itu membosankan. Hal ini dimungkinkan menjadi sebab rendahnya prestasi belajar siswa. Hal ini senada dengan penelitian terdahulu yang menyimpulkan bahwa terdapat hubungan yang signifikan antara minat belajar dengan prestasi belajar matematika (Sirait 2016).

Kemungkinan lain yang menjadi penyebab rendahnya prestasi belajar siswa adalah guru yang kurang kreatif dan inovatif dalam menyampaikan pelajaran, dimana guru masih menggunakan metode ceramah dan kurang melibatkan siswa sehingga siswa menjadi cepat bosan bahkan terkadang siswa hanya duduk, diam, dan tidak ada gagasan atau ide yang ingin diucapkan. Kejenuhan siswa dalam belajar matematika merupakan kondisi mental siswa yang mengalami kebosanan dalam melakukan aktifitas belajar matematika, penyebabnya bisa jadi adalah proses pembelajaran yang didominasi guru serta tidak ada timbal balik dari siswa, dan tidak adanya variasi dalam pembelajaran (Kresma 2014). Padahal sekarang ini pembelajaran sudah berubah dari berpusat pada guru menjadi berpusat pada siswa, dengan demikian ada tuntutan untuk guru agar lebih kreatif 
dan aktif dalam memberikan fasilitas belajar untuk siswanya, misalnya dengan merancang aktivitas belajar siswa yang mendorong siswa untuk dapat mengkonstruksi pengetahuan yang mereka miliki (Sarumaha 2016).

Dari hasil pengamatan di kelas VII G SMP N 3 Sukoharjo semster genap tahun pelajaran 2019/2020, nilai rata-rata ulangan harian siswa dalam belajar matematika masih rendah yaitu belum mencapai KKM (nilai 71). Hal ini dibuktikan dengan nilai yang didapat siswa kelas VII G SMP Negeri 3 Sukoharjo mendapat nilai dibawah 71 (KKM). Berdasarkan hasil pengamatan di kelas VII G SMP Negeri 3 Sukoharjo, masalah yang dihadapi oleh siswa sejauh ini adalah kurangnya keaktifan dan rendahnya prestasi belajar siswa, salah satunya adalah pada materi segiempat dan segitiga. Hal ini dapat dilihat nilai rata-rata hasil ulangan harian matematika materi segiempat dan segitiga di kelas tersebut yaitu 64,5 dengan persentase ketuntasan sebesar 40,6\%. Selain itu, pada kegiatan pembelajaran di dalam kelas siswa hanya bersikap pasif, sedangkan yang aktif adalah guru karena pembelajaran masih menggunakan pembelajaran konvensional dimana guru menjadi pusat pembelajaran, sehingga siswa merasa bosan dan kurang termotivasi dalam belajar matematika. Hal inilah yang dimungkinkan menjadi sebab rendahnya prestasi belajar matematika siswa kelas tersebut.

Melihat hal yang disampaikan di atas, diperlukan suatu perubahan dalam proses pembelajaran untuk memperbaiki kulitas pembelajaran supaya tujuan pembelajaran tercapai. Salah satu alternatif yang dilakukan adalah mengubah model pembelajaran yang konvensional (masih berpusat pada guru) menjadi model pembelajaran yang berpusat pada siswa. Pembelajaran yang berpusat pada siswa akan menumbuhkan kemampuan siswa untuk membangun pengetahuan sendiri, kemampuan untuk berpikir kritis, serta kemampuan untuk membantu teman mencapai ketuntasan belajar baik secara individu atupun secara klasikal (Prasetya 2014). Dengan perubahan tersebut maka nantinya guru diharuskan lebih kreatif dan aktif merencanakan kegiatan belajar yang mendorong siswa untuk mengkonstruksi pengetahuan yang mereka miliki, selain itu siswa juga diharuskan berpikir kritis untuk diri sendiri guna menjelaskan dan mengklarifikasi solusi yang siswa miliki dan juga aktif berkomunikasi dengan siswa lain untuk mendapatkan solusi dari masalah yang diterima (Sarumaha 2016).

Model pembelajaran yang kegiatan belajarnya berpusat pada siswa sudah banyak ditemukan, salah satunya adalah model pembelajaran discovery learning. Hasil penelitian terdahulu menyatakan bahwa pembelajaran discovery learning dapat meningkatkan aktifitas belajar siswa baik secara individu dan berkelompok (Wahjudi 2015). Hal ini juga sejalan dengan penelitian sebelumnya yang mengatakan bahwa ternyata ada pengaruh model pembelajaran discovery learning terhadap motivasi belajar siswa (Patandung 2017). Penelitian lain juga menyebutkan bahwa penerapan model pembelajaran discovery learning lebih baik daripada model pembelajaran langsung pada pembelajaran matematika (Meilantifa 2018). Sejalan dengan hal ini, penelitian lain juga menyatakan bahwa selain dapat meningkatkan prestasi belajar ternyata pembelajaran discovery learning juga dapat meningkatkan minat belajar siswa (Puspitadewi, Saputro, and Ashadi 2016).

Pembelajaran discovery learning merupakan suatu model pembelajaran yang menempatkan guru sebagai fasilitator sedangkan siswa yang aktif menemukan sendiri pengetahuan yang belum dimiliki sehingga pengetahuan tersebut akan lebih melekat lama pada diri siswa (Mawaddah and Maryanti 2016). Jerome Bruner adalah orang pertama yang mengembangkan model pembelajaran discovery learning pada tahun 1915. Discovery learning dianggap oleh Bruner sesuai dengan pencarian pengetahuan secara aktif oleh manusia dan dengan sendirinya dapat memberikan hasil yang baik (Mubarok and Sulistyo 2014).

Terdapat beberapa prosedur yang harus dilakukan pada pembelajaran discovery learning (Wahjudi 2015). Tahapan pertama yang dilakukan tahap stimulation (pemberian rangsangan), pada tahap ini siswa dihadapkan pada sesuatu yang menimbulkan kebingungannya agar muncul keinginan untuk menyelidi sendiri solusinya. Di tahap ini guru memulai pembelajaran dengan mengajukan pertanyaan dan meminta siswa melakukan aktivitas belajar lainnya yang mengarah pada persiapan pemecahan masalah. Stimulasi pada tahap ini berfungsi untuk menyediakan kondisi interaksi belajar yang dapat membantu siswa melakukan eksplorasi pada proses pembelajaran. Tahapan berikutnya adalah problem statement, dimana siswa diberi kesempatan oleh guru untuk mengidentifikasi sebanyak mungkin tentang masalah-masalah yang relevan dengan materi yang diajarkan, kemudian dipilih satu masalah untuk dirumuskan dalam bentuk hipotesis, lalu siswa diberi kesempatan 
mengidentifikasi dan menganalisa masalah yang dihadapi. Tahapan berikutnya adalah data collection (pengumpulan data), siswa menjawab pertanyaan atau membuktikan benar tidaknya hipotesis dengan cara mengumpulkan berbagai informasi yang relevan, membaca literatur, mengamati objek, wawancara dengan narasumber, melakukan uji coba sendiri dan sebagainya. Di sesi ini siswa aktif menmukan sesuatu yang berhubungan dengan permaslahan yang dihadapi, jadi siswa secara tidak langsung menghubungkan masalah yang dihadapi dengan pengetahuan yang dimiliki. Selanjutnya adalah tahapan data processing (pengolahan data), yaitu siswa mengolah data serta informasi yang telah diperoleh melalui wawancara, observasi, dan lainnya yang kemudian ditafsirkan pada tingkat kepercayaan tertentu.pada tahap ini merupakan pembentukan konsep dan generalisasi. Dari generalisasi ini siswa akan memperoleh pengetahuan baru tentang alternatif jawaban yang perlu dibuktikan secara logis. Tahap berikutnya adalah verification (pembuktian), kegiatan pada tahap ini adalah siswa memeriksa kebenaran hipotesis secara cermat dengan menghubungkannya pada hasil data yang telah diolah. Dilanjutkan dengan tahap generalization (menarik kesimpulan/ generalisasi), yaitu proses menarik kesimpulan yang dijadikan prinsip umum dan berlaku untuk semua kejadian atau masalah yang sama dengan memperhatikan hasil verifikasi.

Dengan menggunakan model discovery learning diharapkan dapat membantu siswa meningkatkan keterampilan dan proses kognitif, menimbulkan rasa senang dalam siswa, memungkinkan siswa untuk berkembang dengan cepat dan sesuai dengan kecepatan mereka sendiri, membantu siswa memperkuat konsep dirinya, karena mereka mendapatkan kepercayaan dalam bekerja dengan orang lain, siswa dan guru berperan aktif dalam mengeluarkan ide, membantu siswa menghilangkan skeptisisme atau keraguan (Ponidi et al. 2020).

Dari beberapa hal yang disampaikan, maka perlu dikaji apakah model pembelajaran discovery learning dapat dijadikan alternatif atau solusi pada penelitian tindakan kelas untuk memperbaiki kualitas pembelajaran (prestasi belajar siswa) pada kelas VII G SMP N 3 Sukoharjo tahun pelajaran 2019/2020. Sehingga tujuan dari penelitian ini adalah untuk meningkatkan prestasi belajar siswa dengan menerapkan model pembelejaran discovery learning.

\section{Metode}

Penelitian ini adalah Penelitian Tindakan Kelas (PTK). PTK atau juga disebut classroom action research adalah suatu upaya untuk memperbaiki proses maupun hasil belajar siswa atau meningkatkan mutu pembelajaran, (Fitria, Kristiawan, \& Rahmat, 2019). Pada pelaksanaan PTK dilalui beberapa kegiatan, yaitu planning, acting, observing, dan reflecting, dimana semua kegiatan itu disebut satu siklus PTK (Susilowati, 2018). Jika satu siklus tersebut belum menunjukkan tanda perbaikan pembelajaran, maka dilanjutkan siklus kedua dan seterusnya sampai perbaikan pembelajaran yang diinginkan dapat tercapai.

Penelitian ini dilaksanakan di SMP Negeri 3 Sukoharjo. Tahap-tahap pelaksanaan kegiatan dilakukan selama kurang lebih enam bulan yaitu sejak bulan Januari sampai dengan Juni 2020. Peneliti sebagai guru SMP Negeri 3 Sukoharjo bertindak sebagai subjek yang melakukan tindakan kelas. Teman sejawat sesama guru mata pelajaran matematika sebagai observer. Kepala Sekolah bertindak sebagai subjek yang membantu dalam perencanaan dan pengumpulan data. Subjek yang menerima tindakan adalah siswa kelas VII G SMP Negeri 3 Sukoharjo Semester genap tahun pelajaran 2019/2020 sebanyak 32 siswa.

Teknik pengumpulan data yang digunakan adalah: tes, observasi dan dokumentasi. Tes digunakan adalah jenis tes hasil (achievement test) berupa kuis individu. Tes ini digunakan untuk mengukur pencapaian siswa setelah mempelajari materi. Hal ini dapat juga sebagai alat untuk mengetahui tingkat pemahaman siswa setelah mempelajari materi segiempat dan segitiga dengan menggunakan model pembelajaran discovery learning. Tes yang digunakan adalah tes uraian yang jawabannya berupa isian berbentuk isian singkat atau uraian. Observasi atau pengamatan dilakukan guna memperoleh data yang akurat, dengan menggunakan lembar observasi. Lembar observasi 
digunakan untuk memonitor dan mengevaluasi setiap tindakan agar kegiatan observasi tidak terlepas dari konteks permasalahan dan tujuan penelitian.

Observasi yang digunakan adalah observasi sistematis, yaitu observasi yang dilakukan oleh pengamat dengan menggunakan pedoman sebagai instrumen pengamatan dan observasi nonsistematis yang dilakukan dengan tidak menggunakan instrumen pengamatan. Dokumentasi diperoleh dari hasil kuis siswa, lembar observasi, lembar wawancara, catatan lapangan, daftar siswa, dan foto-foto selama proses kegiatan belajar mengajar. Dokumentasi ini dimaksudkan adalah sebagai bukti-bukti konkret dari penelitian tindakan kelas tersebut.

Instrumen yang digunakan dalam penelitian berupa tes, lembar observasi dan lembar dokumentasi. Tes berbentuk tes tertulis maupun lisan yang dilakukan dalam post test dan kuis individu. Tes ini digunakan untuk mengetahui sejauh mana peningkatan prestasi belajar dengan penerapan model pembelajaran discovery learning. Lembar observasi digunakan untuk mengobservasi pelaksanaan pembelajaran discovery learning. Lembar dokumentasi bertujuan untuk mengetahui data siswa selama kegiatan penelitian berlangsung. Lembar dokumentasi ini berupa, foto-foto kegiatan pembelajaran, daftar hadir kegiatan pembelajaran, daftar hadir, daftar nilai, kartu pasangan soal/jawaban dan sebagainya. Indikator keberhasilan kinerja dalam penelitian ini adalah: (1) siswa dianggap mencapai ketuntasan belajar apabila mencapai lebih dari atau sama dengan KKM (71), (2) pembelajaran dianggap berhasil apabila tingkat ketuntasan kelas mencapai lebih dari atau sama dengan $85 \%$, dan (3) pembelajaran dianggap berhasil apabila siswa secara klasikal nilai rata-rata mencapai lebih dari atau sama dengan 80 .

\section{Hasil dan Pembahasan}

Berdasarkan observasi awal di kelas VII G mata pelajaran matematika dengan materi segiempat dan segitiga diperoleh data dari 32 siswa yang mencapai nilai kriteria ketuntasan minimal (KKM) sebanyak 13 siswa (40,6\%), dengan nilai rata-rata kelas sebesar 64,5. Penelitian ini dilakukan dengan indikator kinerja nilai rata-rata tes siswa sekurang-kurangnya 80,0 dan banyak siswa dengan nilai di atas kriteria ketuntasan minimal (KKM) yaitu 71,0 mencapai lebih dari atau sama dengan $85 \%$.

Pembelajaran matematika di kelas VII G selama ini masuh didominasi oleh dan siswa cenderung tidak aktif sehungga mengakibatkan prestasinya kurang. Salah satu solusi yang dikembangkan adalah penggunaan model pembelajaran yang baru yaitu dengan model pembelajaran discovery learning. Dengan penggunaan model pembelajaran tersebut diharapkan akan menciptakan suasana belajar yang berbeda, bervariasi dan menyenangkan sehingga dapat menarik perhatian siswa, meningkatkan keaktifan siswa yang muara akhirnya meningkatkan prestasi belajar siswa.

Tindakan kelas siklus I dilaksanakan pada hari Selasa, tanggal 18 dan 25 Februari 2020 di SMP Negeri 3 Sukoharjo kelas VII G. Setelah langkah apersepsi dilanjutkan dengan penyampaian materi segiempat dan segitiga pada KD 3.11 Mengaitkan rumus keliling dan luas untuk berbagai jenis segiempat (persegi, persegi panjang, belah ketupat, jajargenjang, trapesium, dan layanglayang) dan segitiga, pada indikator menemukan rumus keliling dan luas segiempat dengan model pembelajaran discovery learning.

Berdasarkan hasil evaluasi pada siklus pertama menunjukkan adanya peningkatan prestasi belajar siswa. Banyak siswa yang mencapai kriteria ketuntasan minimal (KKM) adalah 22 siswa atau $68,8 \%$, rata-rata kelas naik menjadi 72,3. Berdasarkan pengamatan tersebut dapat diketahui bahwa proses pembelajaran pada siklus pertama belum berhasil maksimal dan belum mencapai indikator kinerja yang diharapkan. Hasil yang diperoleh di siklus pertama jika dibandingkan 
dengan prasiklus dapat dilihat pada Tabel 1 . Di tabel tersebut terlihat adanya peningkatan rerata nilai matematika dari 64,5 menjadi 72,3 dan persentase ketuntasan meningkat dari 40,6\% menjadi $68,8 \%$.

Tabel 1. Perkembangan Prestasi Belajar Siswa pada Prasiklus dan Siklus I

\begin{tabular}{ccc}
\hline Prestasi Siswa & Pra siklus & Siklus I \\
\hline Rata-rata & 64,5 & 72,3 \\
\% Siswa mencapai KKM & 40,6 & 68,8 \\
\hline
\end{tabular}

Setelah dievaluasi bersama hasil yang diperoleh pada siklus pertama sudah ada peningkatan prestasi belajar, tetapi belum memenuhi indikator keberhasilan penelitian, sehingga penelitian harus dilanjutkan pada siklus kedua. Berdasarkan hasil pengamatan di siklus pertama dilakukan perbaikan-perbaikan untuk diterapkan pada siklus kedua.

Tindakan kelas siklus kedua dilaksanakan pada hari Jumat, tanggal 6 dan 13 Maret 2020 dengan materi segiempat dan segitiga pada KD 3.11 mengaitkan rumus keliling dan luas untuk berbagai jenis segiempat (persegi, persegi panjang, belah ketupat, jajargenjang, trapesium, dan layang-layang) dan segitiga, pada indikator menemukan hubungan rumus keliling dan luas segitiga. Berdasarkan pembelajaran secara keseluruhan pada tindakan kelas siklus kedua menunjukan adanya peningkatan yang signifikan. Perbandingan hasil siklus pertama dan kedua dapat dilihat pada Tabel 2. Rerata nilai dari 72,3 di siklus pertama naik menjadi 80,2 pada siklus kedua. Persentase siswa yang tuntas KKM juga mengalami kenaikan, dari 68,8\% pada siklus pertama, naik menjadi 90,6\% pada siklus kedua.

Tabel 2. Perkembangan Prestasi Belajar Siswa dari Siklus I ke Siklus II

\begin{tabular}{ccc}
\hline Prestasi Siswa & Siklus I & Siklus II \\
\hline Rata-rata & 72,3 & 80,2 \\
\hline \% Siswa mencapai KKM & 68,8 & 90,6
\end{tabular}

Dari hasil yang diperoleh pada siklus kedua, prestasi belajar matematika meningkat. Pada hasil siklus kedua dapat dilihat bahwa nilai rata-rata yang diperoleh siswa sudah mencapai indikator keberhasilan kinerja penelitian yaitu minimal nilai rata-rata siswa adalah 80. Selain itu untuk presentase ketuntasan kelas juga sudah mencapai indikator keberhasilan kinerja penelitian yaitu minimal $85 \%$. Dari hasil ini maka penelitian pun tidak dilanjutkan ke siklus ketiga atau berhenti di siklus kedua.

Proses pembelajaran dengan menggunakan model pembelajaran discovery learning pada siklus pertama dan kedua terlihat bahwa siswa lebih antusias dengan perasaan senang dalam mengikuti kegiatan pembelajaran. Pembelajaran yang berpusat pada siswa juga mengakibatkan kedisiplinan siswa dalam belajar semakin baik. Siswa tidak lagi menggantungkan kepada guru untuk menerima materi, tetapi mereka berusaha mandiri untuk mencari tahu atau mendapatkan informasi materi baru dari berbagai sumber selain guru. Motivasi dan keinginan untuk mendapatkan informasi baru tentang materi yang dipelajari semakin baik. Hal ini pun berakibat pada prestasi belajar siswa yang ikut meningkat, baik untuk nilai reratanya maupun persentase ketuntansannya, dari siklus pertama ke siklus kedua. Peningkatan tersebut dapat dilihat pada Gambar 1. untuk nilai rerata dan Gambar 2. untuk persentase ketuntasan. 


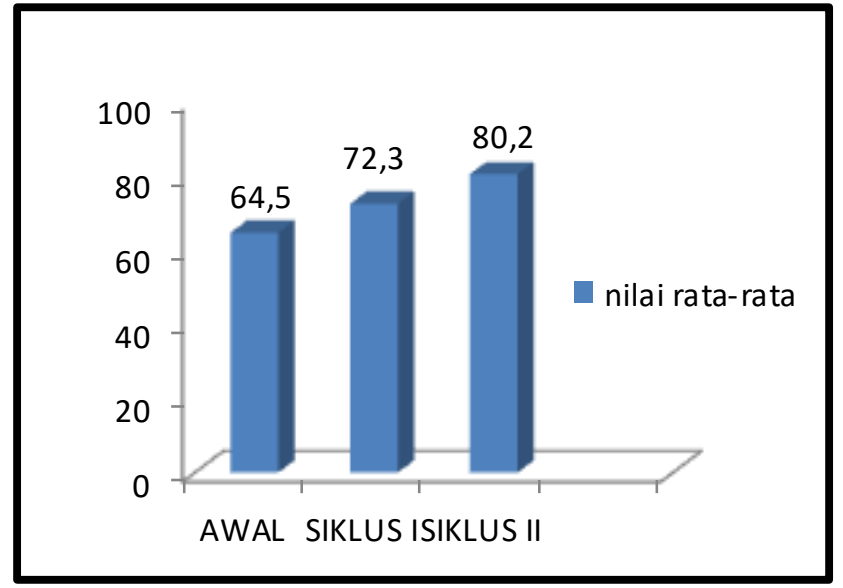

Gambar 1. Peningkatan nilai rata-rata dari prasiklus, siklus I, dan siklus II

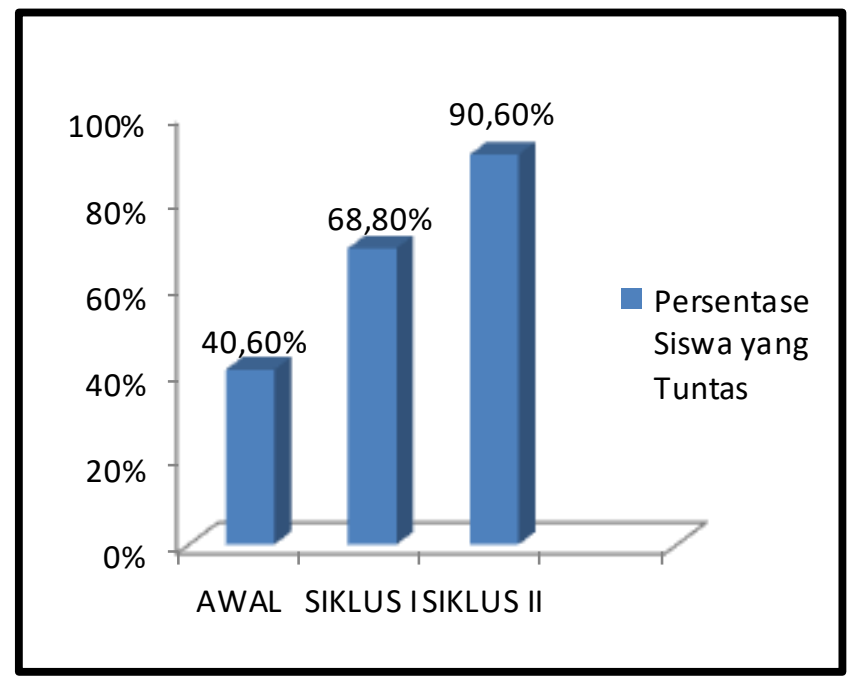

Gambar 1. Peningkatan persentase siswa yang tuntas dari prasiklus, siklus I, dan siklus II

Adanya peningkatan nilai rata-rata kelas maupun persentase ketuntasan kelas dari prasiklus, siklus I, dan siklus II serta ketercapaian indikator kinerja keberhasilan penelitian di siklus II dapat disimpulkan bahwa penerapan model pembelajaran discovery learning dapat meningkatkan prestasi belajar siswa, khususnya untuk prestasi belajar matematika siswa kelas VII G SMP N 3 Sukoharjo semester genap tahun pelajaran 2019/2020.

Hasil penelitian yang diperoleh sejalan dengan hasil penelitian terdahulu yang menyimpulkan bahwa model pembelajaran discovery learning efektif untuk mencapai KKM (Kriteria Ketuntasan Minimun) secara klasikal (Ismunandar 2019). Selain itu hasil penelitian ini juga sedana dengan hasil penelitian sebelumnya yang menyatakan bahwa penerapan model pembelajaran discovery learning efektif untuk meningkatkan hasil belajar siswa (Nurmiati 2019), juga sesuai dengan simpulan penelitian sebelumnya bahwa discovery learning mampu meningkatkan hasil belajar siswa (Kristin 2016). Dengan demikian model pembelajaran discovery learning dapat digunakan 
sebagai alternatif untuk menigkatkan prestasi belajar siswa khususnya di mata pelajaran matematika SMP kelas VII materi segiempat dan segitiga.

\section{Simpulan}

Berdasarkan hasil penelitian dapat disimpulkan bahwa model pembelajaran discovery learning dapat meningkatkan prestasi belajar matematika siswa kelas VII G Semester 2 SMP Negeri 3 Sukoharjo tahun pelajaran 2019/2020.

\section{Referensi}

Ismunandar, Denni. 2019. "Efektifitas Model Discovery Learning Di Kelas VIII Materi Relasi Dan Fungsi.” In Prosiding Seminar Nasional Pendidikan Matematika (SNPM), 62-72.

Kresma, Eka Nella. 2014. "Perbandingan Pembelajaran Konvensional Dan Pembelajaran Berbasis Masalah Terhadap Titik Jenuh Siswa Maupun Hasil Belajar Siswa Dalam Pembelajaran Matematika." Educatio Vitae 1: 152-64.

Kristin, Firosalia. 2016. "Analisis Model Pembelajaran Discovery Learning Dalam Meningkatkan Hasil Belajar Siswa SD.” Jurnal Pendidikan Dasar PerKhasa 2 (1): 90-98. https://doi.org/10.32734/st.v2i2.532.

Mawaddah, Siti, and Ratih Maryanti. 2016. "Kemampuan Pemahaman Konsep Matematis Siswa SMP Dalam Pembelajaran Menggunakan Model Penemuan Terbimbing (Discovery Learning)." EDU-MAT: Jurnal Pendidikan Matematika 4 (1): 76-85. https://doi.org/10.20527/edumat.v4i1.2292.

Meilantifa. 2018. "Penerapan Model Pembelajaran Discovery Learning Dalam Pembelajaran Matematika Pokok Bahasan Lingkaran." Jurnal Ilmiah Soulmath : Jurnal Edukasi Pendidikan Matematika 6 (2): 59-64. https://doi.org/10.25139/smj.v6i2.913.

Mubarok, Chusni, and Edy Sulistyo. 2014. "Penerapan Model Pembelajaran Discovery Learning Terhadap Hasil Belajar Siswa Kelas X Tav Pada Standar Kompetensi Melakukan Instalasi Sound System Di SMK Negeri 2 Surabaya.” Jurnal Pendidikan Teknik Elektro 3 (2): 215-21.

Nurmiati, Baiq. 2019. "Meningkatkan Motivasi Dan Hasil Belajar Peserta Didik Kelas VI Semester Dua Tahun Tahun Pelajaran 2017/2018 Dengan Mengoptimalkan Penerapan Model Discovery Learning Di SD Negeri 2 Cakranegara.” Jurnal Paedagogy 6 (1): 1-7.

Patandung, Yosef. 2017. "Pengaruh Model Discovery Learning Terhadap Peningkatan Motivasi Belajar IPA Siswa." Journal of Educational Science and Technology (EST) 3 (1): 9-17. https://doi.org/10.26858/est.v3i1.3508.

Ponidi, Winia Waziana, Marilin Kristina, and Miswan Gumanti. 2020. "Model of Utilizing Discovery Learning to Improve Mathematical Learning Achievements." Attractive: Innovative Education Journal 2 (1): 41-48.

Prasetya, Sukma Perdana. 2014. "Memfasilitasi Pembelajaran Berpusat Pada SIswa." Jurnal Geografi.

Puspitadewi, Rizky, Agung Nugroho Catur Saputro, and Ashadi. 2016. "Penerapan Model Pembelajaran Discovery Learning Untuk Meningkatkan Minat Dan Prestasi Belajar Siswa Pada Materi Kelarutan Dan Hasil Kali Kelarutan Kelas Xi Mia 3 Semester Genap SMA N 1 Teras Tahun Pelajaran 2015/2016.” Jurnal Pendidikan Kimia (JPK) 5 (4): 114-19.

Sarumaha, Yenny Anggreini. 2016. "Perubahan Pembelajaran Yang Berpusat Pada Guru Ke 
Berpusat Pada Siswa." Intersection Journal 1 (1): 1-10.

Sirait, Erlando Doni. 2016. "Pengaruh Minat Belajar Terhadap Prestasi Belajar Matematika." Formatif: Jurnal Ilmiah Pendidikan MIPA $6 \quad$ (1): 35-43. https://doi.org/10.30998/formatif.v6i1.750.

Siregar, Nani Restati. 2017. "Persepsi Siswa Pada Pelajaran Matematika: Studi Pendahuluan Pada Siswa Yang Menyenangi Game." In Prosiding Temu Ilmiah X Ikatan Psikologi Perkembangan Indonesia, $224-32$. https://www.google.co.id/search?q=Persepsi+siswa+pada+pelajaran+matematika\%253A+stu di+pendahuluan+pada+siswa+yang+menyenangi+game+Nani+Restati+Siregar1+1Mahasiswa +Program+Doktor+Psikologi+Universitas+Gadjah+Mada\&oq=Persepsi+siswa+pada+pelajar an+matematika.

Wahjudi, Eko. 2015. "Penerapan Discovery Learning Dalam Pembelajaran IPA Sebagai Upaya Untuk Meningkatkan Hasil Belajar Siswa Kelas IX-I Di SMP Negeri 1 Kalianget.” Jurnal Lentera Sains (Lensa) 5 (1): http://artikel.dikti.go.id/pelatihan/index.php/pojs04/article/view/571. 